\title{
THE EFFECT OF 2,4-D AND 2M-4K ON SOME OIL FLAX VARIETIES GROWN UNDER DIFFERENT ENVIRONMENTAL CONDITIONS.
}

\author{
Juhani Paatela and R. S. Dunham. ${ }^{1}$
}

Received 26. 10. 1949

Several papers have been published during the last few years on using growth regulating herbicides for weed control in oil flax $(1-22)$. Many of the authors suggest the use of methoxone or 2,4-D. However the dosages recommended vary considerably. In the U.S.A. and Canada the amine compounds of 2,4-D are commonly used by farmers and the amount of 2,4-D acid in amine form used for selective spraying in flax varies from 3 to 4 ounces per acre or $210-280$ grams per hectare. In ester compounds the dosage recommendations vary from 1 to $2 \mathrm{oz}$. per acre or 70 - 140 grams per hectare. According to preliminary information on flax the best dosage of methoxone in Minnesota seems to be about $4-6$ ounces per acre or 280 420 grams per hectare. In Europe the dosages recommended for flax vary from 300 to 1000 , sometimes up to 2000 grams per hectare using methoxone and from 200 to 1000 grams of amine salt of 2,4-D per hectare.

Tandon (18), Dunham and Tandon (9), Dunham and Robinson (8) as well as DAvidson (5) have found that there are differences among oil flax varieties in susceptibility to 2,4-D. The difference was greatest between the most tolerant Redwing and the susceptible Crystal. "An application of four times the amount of 2,4-D that reduced the yield of Crystal and B 5128 did not injure Redwing» (9). There has been shown also (16) that there are differences in susceptibility and injury in flax when the rate of growth after spraying was different.

In the summer of 1949 an experiment designed to throw more light on the relation of rate of growth to susceptibility was carried out at St. Paul, Minnesota, in co-operation with the Division of Agronomy and Plant Genetics of the University of Minnesota. Seeds of the three varieties tested (Redwing, Dakota, Minerva) were sown in 4 inch pots May 25 and placed in an air conditioned chamber (about $50^{\circ}$ $\mathrm{F}$ or $10^{\circ} \mathrm{C}$ ) under artificial light. When these plants reached about 2 inches in height,

1 Doctor of Agronomy; Professor, Division of Agronomy and Plant Genetics, University of Minnesota, St. Paul, Minn., and president, North Central Weed Control Conference, U.S.A. and Canada. 
seeds of the same varieties were sown in pots in the greenhouse. Nine days after reaching the cotyledon stage the plants in the greenhouse were at the same stage as the plants in the cool chamber, where they had reached the cotyledon stage 24 days earlier. In both greenhouse and cool room plants averaged $7.5 \mathrm{~cm}$. tall with 12 true leaves at the time of spraying, but they varied from 6.6 to $8.5 \mathrm{~cm}$. tall and from 10 to 13 leaves. Eight replicates of each variety were sprayed both in the cool room and the greenhouse with $2 \mathrm{M}-4 \mathrm{~K}$ and $2,4-\mathrm{D}$ at 6 ounces per acre or 420 grams per hectare of effective substance. Half of the sprayed pots as well as four check pots of each variety in the cool chamber were transferred into the greenhouse and similarly treated pots from the greenhouse to the cool room. Three additional replicates of Redwing and Dakota grown in the cool chamber were sprayed with 12 and 18 ounces per acre or 840 and 1260 grams per hectare of methoxone and 2,4-D, and after that transferred into the greenhouse. Four days later notes were taken on the average stem curvature using a scale of $0-3$ with $0=$ erect, $1=$ slightly bent, $2=$ more than $45^{\circ}$ bent, $3=90^{\circ}$ or more bent:

\section{Treatment}

Continuous slow growth

Started and kept in cool chamber

6 oz. methoxone ...........

6 oz. $2,4-\mathrm{D} \ldots \ldots \ldots \ldots \ldots \ldots$

12 oz. methoxone ...........

12 oz. $2,4-\mathrm{D} \ldots \ldots \ldots \ldots \ldots \ldots$

18 oz. methoxone ...........

18 oz. $2,4-\mathrm{D} \ldots \ldots \ldots \ldots \ldots \ldots$

Slow growth before spraying

Started in cool chamber, transferred to greenhouse

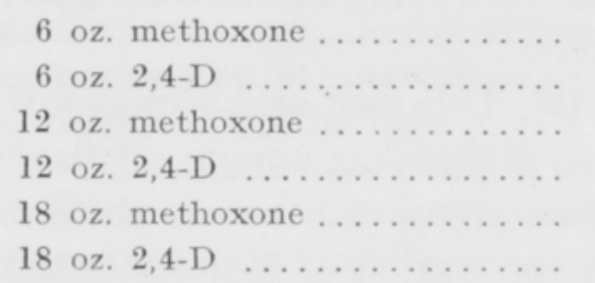

Fast growth before spraying

Started in greenhouse, transferred to cool room
6 oz. methoxone...........
6 oz, 2,4-D

Continuous fast growth

Started and kept in greenhouse

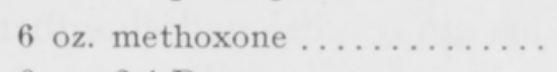

6 oz. $2,4-\mathrm{D} \ldots \ldots \ldots \ldots \ldots \ldots$.

\begin{tabular}{|c|c|c|}
\hline & Response $^{1}$ & \\
\hline Redwing & Dakota & Minerva \\
\hline 0.1 & 0.1 & 0.0 \\
\hline 0.1 & 0.0 & 0.0 \\
\hline 0.1 & 0.2 & - \\
\hline 0.0 & 0.1 & - \\
\hline 0.1 & 0.3 & - \\
\hline 0.1 & 0.1 & - \\
\hline
\end{tabular}

$\begin{array}{lll}0.1 & 0.2 & 0.1 \\ 0.0 & 0.1 & 0.0 \\ 0.3 & 0.2 & - \\ 0.1 & 0.2 & - \\ 0.3 & 0.4 & - \\ 0.2 & 0.4 & -\end{array}$

1 Response $=$ number of affected plants times scale $0-3$ for degree of bending divided by total number of plants. 
There are clear differences among some of the treatments. The plants which were kept in the cool chamber and grew slowly did not show more than very slight bending in spite of rather high dosages of 2,4-D and methoxone, up to $18 \mathrm{oz}$. per acre or 1260 grams per hectare, whereas the plants grown in the greenhouse before spraying and placed in the cool chamber after spraying showed distinct bending with a dose of $6 \mathrm{oz}$. per acre or 420 grams per hectare. The plants grown continuously in the greenhouse bent more distinctly than those grown there only after spraying or those grown continuously in the cool chamber. The plants transferred to the cool chamber just after spraying showed distinctly more bending than those grown continuously in the greenhouse. - Differences in stem curvature were also observed between varieties although they were not very distinct. - On the average the effect was more distinct with 2,4-D than methoxone. The lower parts of the stems did not recover completely but were very nearly prostrate on the ground in the case of plants sprayed with 2,4-D while those sprayed with methoxone showed either slight effect or none at all. - Earlier it has been shown (16) that rapid growth during the next few days following treatment resulted in more bending than when growth was slow after spraying.

After recovery from bending there were differences in height between the treated and untreated plants, however differences were smaller at flowering time:

Treatment

Slow growth before spraying

Started in cool chamber, trans-

ferred to greenhouse

Untreated

$6 \mathrm{oz}$. methoxone 100

6 oz. 2,4-D ..............

12 oz. methoxone ............

12 oz. 2,4-D ..............

$18 \mathrm{oz}$. methoxone ...........

18 oz. $2,4-\mathrm{D}$

Continuous fast growth

Started and kept in greenhouse

Untreated .............. 48=100

6 oz. methoxone ........... 84

6 oz. 2,4-D

A verage 6 oz. meth. .........

6 oz. $2,4-\mathrm{D}$
Redwing

$54=100$

89

80

65

69

56

Height in $\mathrm{cm}$.

$\begin{array}{rr}\text { Dakota } & \text { Minerva } \\ 55=100 & 54=100 \\ 91 & 74 \\ 64 & 70 \\ 69 & - \\ 60 & - \\ 73 & - \\ 55 & -\end{array}$

\begin{tabular}{lll}
84 & 76 & 94 \\
73 & 70 & 79 \\
\hline 92 & 84 & $84=87$ \\
81 & 67 & $75=74$
\end{tabular}

On the basis of heights Redwing seems to be most tolerant, Dakota and Minerva clearly more susceptible, which agrees with the results reported earlier $(8,9,18)$. Sprayings with 2,4-D have been without exception more injurious than sprayings with methoxone, which also agrees with the earlier findings $(16,21)$. Results with the plants kept in the cool chamber after spraying unfortunately are lacking because of a breakdown of the cooling machinery. In the plants transferred from the cool 
room just before spraying to the greenhouse there was either no bending or very slightly bending. However there is clearly an injurious effect on the height of sprayed plants and the injury is greatest for plants treated with highest concentrations of 2,4-D or with methoxone.

\section{Summary.}

Some results of a preliminary test conducted at University Farm, St. Paul Minnesota have been given. The following conclusions have been made:

1. Flax plants that had grown slowly both before and after spraying and those that had grown slowly up to the time of spraying did not show as distinct stem bending or as great reduction in height as did those which grew rapidly before spraying.

2. Varietal differences in the response to methoxone and 2,4-D were apparent between Redwing, Dakota, and Minerva. Redwing was most tolerant with Dakota and Minerva more susceptible.

3. The effect of spraying oil flax with methoxone was not as severe as with 2,4-D when measured by the amount and degree of stem curvature and the reduction in height. Equivalent amounts of the effective substance in each herbicide were used.

REFERENCES.

(1) Bakкe, A. L. 1947. Chemical control of weeds in flax. Proc. Fourth Ann. North Central Weed Control Conf., No. 202.

(2) - - \& Staniforth, David W. 1948. The control of weeds in flax by the use of chemicals. Proc. Fifth Ann. North Central Weed Control Conf., No. 34.

(3) Blackman, G. E. \& Holly, K. 1948. Weed control in linseed and flax. Agriculture, 54, p. 538- 542.

(4) Carder, A. C. 1948. The effect of 2,4-D on flax. Proc. Fifth Ann. North Central Weed Control Conf., No. 35 .

(5) Davidson, J. G. 1948. Effect of 2,4-D as a selective herbicide in linseed flax. Ibid., No. 37.

(6) Dunham, R. S. 1947. Response of Koto flax to application of 2,4-D. Proc. Fourth Ann. North Central Weed Control Conf., No. 204.

(7) - - \& Robinson, R. G. 1948. Effect of 2,4-D on flax with and without weeds. Minn. Agr Exp. Sta. Misc. Jour., Series No, 640.

(8) —- — \& - 1948. Response of flax varieties to 2,4-D. Series No. 641.

(9) - - \& TAndon, R. K. 1948. Using 2,4-D on flax. Repr. Minn. Farm and Home Sci. V, No. 2.

(10) Ficht, J. P. 1947. 2,4-D sprays in cereals, flax, wheat, oats, and barley. Proc. Fourth Ann. North Central Weed Control Conf., No. 218.

(11) — 1948. Effect of 2,4-D as a selective herbicide in growing crops of flax. Proc. Fifth Ann. North Central Weed Control Conf., No. 42.

(12) Friesen, H. A. 1948. Effect of 2,4-D as a selective herbicide on linseed flax. Ibid., No. 43.

(13) Hagsand, Erik \& VäÄrtnöU, Herman 1949. Hormonderivat i kampen mot ogräs. Växtodling, 4, p. 8 - 30. Uppsala. 
(14) Leggett, H. W. 1947. The effect on the yield of wheat, oats, barley and flax sprayed with three formulations of 2,4-D, five concentrations, and at three stages of growth. Proc. Fourth Ann. North Central Weed Control Conf., No. 220.

(15) Olson, P. J. \& Zalik, S. 1947. Effect of 2,4-D on cereals and flax. Ibid., No. 221.

(16) PaAtela, Juhani 1949. Artificial hormones and weed control in oil flax cultivations. Agricultural Exp. Activities of the State, 131, p. 1-52.

(17) Pavlychenko, Thomas K. 1948. Effect of various systemic hormone herbicides on flax from emergence to 21 day stage. Proc. Fifth Ann. North Central Weed Control Conf., No. 45.

(18) TANDON, R. K. 1949. The response of flax to rates and formulations of 2,4-dichlorophenoxyacetic acid. Repr. Agr. Jour., 41, p. 213-218.

(19) Taylor, D. K. 1948. Effect of 2,4-D as a selective herbicide in flax. Proc. Fifth Ann. North Central Weed Control Conf., No. 48.

(20) Zalik, Saul \& Olson, P. J. 1948. Effect of 2,4-D on flax. Ibid., No. 49.

(21) Åberg, Ewert, Hagsand, Erik \& VäÄrtnöU, Herman 1948. Hormonderivat i kampen mot ogräs. V. Fältförsök 1946-1947. Växtodling, 3, p. 8-64. Uppsala.

(22) —- 1949. Hormonderivat i kampen mot ogräs. VIII. Ibid., 4, p. 73-99.

S E L O S T S.

\title{
ERÄIDEN ERILAISISSA KASVUOLOSUHTEISSA KASVANEIDEN ÖLJYPELLAVA- LAJIKKEIDEN HERKKYYDESTÄ 2,4-D JA 2M-4K-TEKOHORMONEILLE.
}

\author{
Juhani Paatela ja R. S. Dunham.
}

Viime vuosina eri puolilla maailmaa julkaistujen lukuisten tutkimusten mukaan tekohormonit ovat sopivia käytettäviksi öljypellavaviljelyksien rikkaruohontorjunnassa (1-22). Suositellut ainemäärät vaihtelevat kuitenkin huomattavasti mm. käytetystä valmistetyypistä riippuen. Myös kasvunopeudella (16) ja viljellyllä lajikkeella $(5,8,9,18)$ on todettu olevan merkitystä tekohormonien vaikutuksen voimakkuuteen nähden. Minnesotan maatalousyliopiston kasvinviljely- ja kasvinjalostusosastolla suoritettiin kesällä 1949 koe, jonka tarkoituksena oli selvitellä, miten eräiden öljypellavalajikkeiden herkkyys 2M-4K- ja 2,4-D-tekohormoneille vaihtelee pellavien erilaisesta kasvunopeudesta riippuen. Saatujen tulosten perusteella on vedetty seuraavat johtopäätökset:

1. Öljypellavat, jotka kasvoivat hitaasti sekä ennen että jälkeen ruiskutuksen, samoin kuin ne, jotka kasvoivat ruiskutushetkeen saakka hitaasti, eivät taipuneet niin selvästi eivätkä jääneet niin lyhyiksi kuin pellavat, jotka kasvoivat nopeasti ennen käsittelyä.

2. Tutkituista lajikkeista Redwing oli selvästi kestävämpi käytetyille tekohormoneille kuin Dakota- ja Minerva-nimiset lajikkeet.

3. $2 \mathrm{M}-4 \mathrm{~K}$ ei vaikuttanut niin haitallisesti öljypellavaan kuin 2,4-D ilmaistuna kasvuston taipumisena ja pituudenkasvun estymisenä. Kummassakin käsittelyssä tehoavaa ainetta annettiin yhtä paljon. 